\title{
Deployment of Faculty in AACSB Accredited Accounting Programs in the U.S.: Implications for Smaller Academic Units
}

\subsection{Introduction}

Accounting bachelor's and master's level degree programs in the United States usually have the primary mission of preparing students for careers in professional accounting practice in corporations or accounting firms or for further study at a higher academic level. In fact, faculty members in accounting programs accredited by the Association to Advance Collegiate Schools of Business (AACSB) have traditionally been required to regularly interact with professionals in practice, more so than other faculty in the business school. Professional interaction of accounting faculty benefits both faculty and student professional development. It helps faculty remain current and relevant in the accounting classroom and helps students develop much-needed professional skills.

The mission of an accounting education program that offers the doctoral degree is to prepare students for accounting academic careers. Such accounting programs focus heavily on academic research and devote most of the faculty resources to that end. However, the accounting academic unit (e.g., accounting department or School of Accountancy) ${ }^{1}$ that houses the doctoral program would probably also offer bachelors and masters level programs in accounting and would need to engage some faculty in interaction activities with professional practice for the development of these students. Larger programs that have sufficient faculty resources and/or flexibility in how faculty resources are used ${ }^{2}$ may not experience many difficulties accomplishing both a robust academic research program and meaningful professional interaction activities for doctoral as well as undergraduate and master's level students and faculty. However, in smaller accounting departments offering the doctoral degree, where resources are scarce or

\footnotetext{
${ }^{1}$ Accounting department and accounting academic unit will be used interchangeably in this paper to refer to the unit within the business school, division, or college that houses the accounting program. Schools of Accountancy within the larger business unit are included in the accounting academic unit as used in this paper. Similarly, business school and business unit will be used interchangeably in this paper. The business unit includes all forms of the business program: school, division, and college.

${ }^{2}$ When professionally oriented faculty members are hired in full-time positions they are often hired in non-tenure track slots. Some smaller universities may not allow or may place limits on the number of faculty in non-tenure track positions.
} 
inflexible, effective faculty deployment for both impactful scholarship and high quality professional interaction activities can be more challenging.

There are other reasons to be concerned about faculty deployment issues in accredited accounting programs. Accounting academia is currently facing a shortage of terminally qualified faculty as babyboomers retire and the demand for accounting education grows (Boyle et al, 2015a; Pathways Commission, 2012). At the same time, due to the role accounting plays in the U.S. economy in the allocation of resources, there is an effort in the profession to make the accounting academic community more responsive to the needs of accounting and auditing practice. The U.S. Treasury commissioned a special committee in 2008 to study the auditing profession. Its recommendations have led the AACSB and business schools to consider integrating professionally oriented faculty more fully into accounting and business education programs. If successful, this effort should help address both the shortage of terminally qualified faculty and the need for accounting academia to be more responsive to accounting and auditing practice.

The purpose of this paper is to investigate faculty deployment practices in AACSB accredited accounting programs in the U.S., both doctoral and non-doctoral programs, with respect to research oriented faculty and professionally oriented faculty. Deployment practices followed by large accounting doctoral granting programs may be helpful to smaller programs, especially doctoral programs that have resource challenges. Such smaller programs usually offer accounting degrees at all levels: bachelors, masters and doctoral. Deployment practices showing efficient and effective use of faculty resources to accomplish a broad mission should be helpful to both university and program level administrators of smaller programs. This paper should also help inform university level administrators of the need for more flexibility in faculty hiring outside the tenure track position. Accrediting agencies can use the recommendations from this paper in designing or revising future standards for professional academic fields such as accounting. 
The literature on deployment of accounting faculty mostly relate to the pros and cons of accreditation standards for use of professionally qualified faculty. More recent research in this area provides reasons why accounting academia should increase the use of professionally oriented faculty in the accounting program, not only to help with the ongoing shortage of faculty in the profession but also to help strengthen the relationship between academia and accounting practice. This paper adds to research in this area by documenting a trend in faculty deployment and suggesting a minimum level of professionally oriented faculty for smaller accounting academic units. It also adds to the literature regarding the characteristics and needs of smaller accredited accounting units versus larger units as such programs seek to maintain high quality in accounting education.

\subsection{Background}

The AACSB is an accrediting agency for business schools in the U.S. and abroad. It has been setting high standards for university business programs and providing accreditation services since 1919 . The purpose of AACSB accreditation is to promote continuous improvement in business education programs by connecting business education with business practice. It encourages business schools to "hold themselves accountable for improving business practice through scholarly education and impactful intellectual contributions" (AACSB, 2016b, 2). It adopted its first standards for accounting degree programs in 1980. Separate accounting accreditation is an extension of the broader business unit accreditation and is only available to accounting programs within the larger accredited business unit. The accounting standards are closely aligned with the business standards (AACSB, 2016a, 3).

The accreditation process involves a self-study of the unit's compliance with the standards, followed by a peer review. The peer review team reviews the business or accounting unit's processes and, if warranted, recommends it for accreditation. Accredited programs continue to undergo peer review for accreditation maintenance every five years. The AACSB periodically reviews its standards and accreditation processes 
with the academic community and its stakeholders to make sure they remain relevant and effective in encouraging continuous improvement in business programs (AACSB, 2016a, 3).

The purpose of having separate AACSB standards for accounting accreditation is to support accounting as a learned profession by identifying and recognizing high quality accounting education programs (AACSB, 2016a, 4). The accounting profession has attributes similar to those of other learned professions such as law and medicine, including: 1) a code of professional conduct and integrity, 2) the expectation of continuing education, 3) partnerships between the professional practice and academia, 4) a requirement for certification and licensure, and 5) on-going quality assurance or accreditation standards for academic programs (AACSB, 2016a, 4). It is this "professional" nature of accounting that the AACSB seeks to promote and uphold through separate accounting accreditation. According to the AACSB, high quality accounting education programs are those that produce excellent graduates, engage in impactful scholarship, and rely on "high quality interactions between academia and professional practice" (AACSB, 2016a, 4).

\subsection{The Pathways Commission}

In 2008, the U.S. Department of the Treasury developed a special committee to study the practice of accounting and auditing in the U.S. It was called the Advisory Committee on the Auditing Profession. The committee recommended that the accounting profession should make sure accounting education programs are designed to meet the needs of accounting and auditing practice. That recommendation led to the creation of the Pathways Commission ${ }^{3}$ which was given the charge of studying accounting higher education and making recommendations for developing and maintaining a strong "community of students, academics, practitioners and other leaders in the practice and study of accounting" (Pathways Commission, 2012, 9). The Commission released its report in 2012. In one recommendation it calls for

\footnotetext{
${ }^{3}$ The Pathways Commission is a task force of leaders in the accounting profession and the accounting academic community that was created in response to the report of the U. S. Treasury's Advisory Committee on the Auditing Profession. The Commission was created by the American Institute of Certified Public Accountants in conjunction with the American Accounting Association.
} 
business schools and accounting programs to integrate professionally oriented faculty more fully into accounting education programs (Pathways Commission, 2012, 49).

The Pathways Commission recommended that accounting educators and practitioners build a learned profession for the future by integrating accounting research, education and practice (Pathways Commission, 2012, 49). The Commission pointed to a "void" that exists between accounting research and accounting practice (51). Behn et al (2012) explains that accounting practitioners are not consumers of academic accounting research, and in addition, accounting researchers have difficulty getting access to the data needed to address current issues in accounting practice (597). This is different from other learned professions such as law and medicine where research is more directed toward issues facing legal and medical practice (Behn et al, 2012, 597).

The Commission recognized the shortage of terminally qualified faculty in the accounting profession. It recommended that the accounting profession take steps to meet the shortage by introducing more flexible ways for practitioners and others to enter accounting academia and obtain the terminal degree (Pathways Commission, 2012,31). A study by Boyle et al (2015b) shows that professionally oriented faculty that currently work in accounting education do not feel they are being used to the fullest extent possible in U.S. institutions. Boyle et al surveyed 267 professionally oriented faculty employed in accounting programs nationwide. Professional faculty indicated that they received little training, feedback or guidance and their participation in research activities in the accounting program was limited. Many expressed an interest in full time teaching and some want tenure track positions. Boyle et al (2015b) concluded that professionally oriented faculty have aspirations for full time and/or tenure track positions and need the terminal degree for this purpose.

The professional doctorate degree, or doctorate in business administration (DBA) degree, has grown in popularity in accounting academia in recent years. Such programs are offered at Case Western Reserve University, Pace University, Georgia State University and Kennesaw State University. Integrating 
professionally oriented faculty and faculty from professional programs such as these into accounting education programs will help smaller institutions cope with the shortage of accounting PhDs on the market. The effort will also help close the gap between accounting research and accounting practice as practitioners complete the DBA degree and enter academia. This new group of faculty with the professional doctorate degree can be expected to complete research projects more related to issues facing accounting and auditing practice.

\subsection{AACSB Focus on Professionally Oriented Faculty}

The integration of practitioners into the business school is a prominent feature of the AACSB 2013 revised business and accounting standards. The 2013 standards require business schools and accounting departments to embrace innovation, impact and engagement. They emphasize that engagement with management practitioners requires business schools to have a balance of academic and professional faculty (Trapnell, 2015, 48). The standards state that quality business education cannot be achieved when professional engagement is missing from the business program or when it does not intersect with academic engagement in meaningful ways (AACSB, 2016b, 2). As for accounting education, the standards suggest that its very existence is at the intersection of accounting theory and accounting practice. Accredited accounting units should be firmly grounded in, not only academics, but also the professional practice of accounting, business and management (AACSB, 2016a, 31).

In the 2003 standards, faculty could be academically qualified (AQ) or professionally qualified (PQ). There was only one category in which professionally oriented faculty could be used. To encourage more use of professionally oriented faculty, the 2013 standards provide two new categories so that there are now three categories where professionally oriented faculty may be used. The new faculty categories are: scholarly academic (SA), practice academic (PA), scholarly practitioner (SP) and instructional practitioner (IP). Faculty members not classified are labelled as Other (OT). Professionally oriented faculty may be used in the PA, SP and IP categories. 
The new categories are described as follows:

SA faculty members are the academic scholars of the business school. This category is equivalent to the AQ (academically qualified) category in the 2003 standards. These faculty members usually have the doctoral degree in the area of teaching and sustain currency and relevance through scholarship and related activities. SA status is usually granted to newly hired faculty who earned the doctoral degree within the past five years.

PA faculty members also have the doctoral degree in the teaching area but sustain currency and relevance through professional engagement, interaction and other practice-related activities. This is a new category compared to the 2003 standards. These are faculty members that augment their initial preparation as academic scholars with engagement activities substantially connected to practice. These faculty members may continue to produce research in some institutions but not as much as SA faculty. This category could be used to accommodate the new breed of accounting faculty entering institutions with the DBA degree.

SP faculty usually have the master's degree in the teaching field and sustain currency and relevance through continued professional experience, professional engagement and interaction, as well as scholarship related to their professional background and experience. This is also a new category compared to the 2003 standards. This category will allow faculty without the terminal degree that are interested in producing accounting research to be rewarded for that effort.

IP faculty also have the master's degree in the teaching field and sustain currency and relevance through continued professional experience and professional engagement and interaction related to their professional background and experience. Faculty classified as IP do not engage in academic research. This category is equivalent to the PQ (professionally qualified) category in the 2003 standards.

The standards require that (AACSB, 2016b, 43):

- at least 40 percent of the faculty be classified as SA,

- 60 percent be classified as SA + PA + SP, and

- 90 percent be classified as SA + PA + SP + IP.

This means that only 10 percent of faculty can be classified as OT.

The accounting academic unit must develop criteria for the classification of faculty into the categories.

Classification should be based on initial academic preparation, professional experience, ongoing academic and professional engagement, and ongoing professional interactions, and it should be consistent with the mission of the unit (AACSB, 2016a, 33). To remain current and relevant in the classroom, a faculty member's engagement and interaction activities should be aligned with the primary teaching 
responsibility (33-34). Most of the research conducted by the unit will probably be conducted by SA faculty. On the other hand, most of the professional engagement and interaction with accounting practitioners will probably be conducted by IP faculty. Faculty classified as PA and SP, the two new faculty categories, may contribute to both research and professional engagement and interaction activities. If a unit has all of its faculty members classified into the SA category, SA faculty may be required to conduct some professional engagement activities since there would be no other faculty to conduct these activities. Of course, faculty in all categories will likely be involved in curriculum activities (e.g., teaching), especially in smaller business schools. How schools deploy accounting faculty to accomplish both research and professional engagement and interaction activities is the subject of this paper.

The remainder of this paper is organized as follows. The next section reviews the AACSB accounting standards and the accounting literature related to academic and professional engagement and interaction activities with focus on activities unique to the accounting program. Curriculum related activities are similar for all faculty in the business school and are not discussed in detail in this paper. The research questions and methodology are presented in Section 4 followed by the results and discussion of findings in Section 5. The final section of the paper covers conclusions and recommendations for accounting program heads, business school or college Deans and university-level administrators.

\subsection{AACSB Accounting Standards and Accounting Faculty Activities}

\subsection{Mission of the Accredited Accounting Program}

AACSB standards define the accounting academic unit as one in which "accounting education is the predominant focus across degree programs, research and outreach activities that are focused on preparing graduates for professional accounting careers in industry, public accounting, government, or non-profit organizations, or for further study at the graduate level, including preparation for accounting academic careers" (AACSB, 2016a, 7). The AACSB does not require a defined type of administrative structure for the program. It only requires that the structure used provide proper oversight and accountability related to 
accounting education and be appropriate to sustain excellence and continuous program improvement (AACSB, 2016a, 9). Normally, the program director or department head of the accredited accounting unit would have a doctoral degree in the accounting discipline.

The mission of the AACSB accredited accounting unit includes production of excellent accounting graduates, impactful scholarship, and high quality interactions between the program and professional accounting practice (AACSB, 2016a, 4). The requirement for high quality interactions with accounting practice is a unique feature of the accounting accreditation standards. Other programs in the business unit, while encouraged to engage with business professionals in substantive ways, are not required to regularly interact with professionals as required of accounting programs. In addition, unlike the other business programs, the accredited accounting program must operate according to a strategic plan with expected mission, mission outcomes, strategies and activities. AACSB standards do require strategic planning for the business school which includes planning for all programs offered within the school. But accounting is the only program within the school required to have a separate strategic plan. Both academic engagement activities and professional engagement and interaction activities must be included in the strategic plan of the accounting unit.

The mission of accredited accounting programs includes both research and teaching. Doctorate granting programs must focus most of its research activities on creating new knowledge while bachelors and masters level programs may focus more on applied research and research related to teaching and learning. Garahan et al (2007) used survey research to investigate the perceived benefits and challenges of accounting accreditation. They surveyed administrators of 66 accounting programs that were either accredited or in candidacy for accreditation. Of 63 responses, 32 programs listed the mission as research and 31 listed the mission as teaching. Sixteen (16) of the institutions offered the doctoral degree in accounting. A more recent study by Bitter (2014) surveyed 166 accredited accounting programs to determine perceptions of administrators regarding the benefits of accounting accreditation. Of the 96 responses received, $18 \%$ or 17 accounting administrators listed the mission as both teaching and research. 
Another 48 respondents (50\%) listed the mission as teaching while the remaining 31 (32\%) listed the mission as research. Thirty (30) of the respondents in the Bitter study offered the doctoral degree in accounting.

Corcoran (2006) separated accredited business programs by highest degree conferred (i.e., doctorate, masters, bachelors) and implied this division reflected the different missions of the programs at each level. He surveyed 273 faculty members at all ranks in accredited business programs in his study of differences and similarities among institutions at the three program levels. He found significant differences among the levels on variables such as GMAT score, percent of full time faculty with doctorate and size of operating budget. He found that faculty at all ranks agreed that "accreditation should formally distinguish among doctoral, master's and bachelor's programs for branding purposes" (Corcoran, 2006, 45). This research follows the example set by Corcoran and compares deployment practices of doctorategranting units to that of non-doctorate granting units.

\subsection{Academic Engagement Activities}

Academic engagement is faculty involvement in producing intellectual contributions. Intellectual contributions are scholarly activities in that they produce peer-reviewed research papers that are widely distributed, usually by publication in academic journals. Intellectual contributions produced by faculty of the accredited accounting program should have impact on the theory, practice, and/or teaching of accounting, business, and management (AACSB, 2016a, 16).

Intellectual contributions fall into three categories (AACSB, 2016a, 16):

1. Basic or discovery scholarship generates or communicates new knowledge and understanding or development of new methods that impact the theory, practice or teaching of accounting and management.

2. Applied scholarship synthesizes new understandings or interpretations of knowledge or technology or develops or refines new technologies, processes, methods or uses based on existing knowledge. Intellectual contributions in this area impact accounting and business practice. 
3. The scholarship of teaching and learning develops and advances new insights and teaching content and methods that impact learning behavior. Intellectual contributions in this area impact teaching or pedagogy related to accounting and management.

In his research on accredited business programs' similarities and differences, Corcoran (2006) suggested that the AACSB has created a "de facto tiering scheme" for business programs based on research productivity (42). Basic research is usually the focus of business schools offering doctoral programs. Schools that offer bachelors level programs may focus its research on applied scholarship related to practice or to teaching and learning. Schools with a mix of bachelors and masters programs are encouraged to have a balance of research among basic scholarship, applied scholarship and the scholarship of teaching and learning. To meet the needs of accounting and auditing practice, accounting educators are encouraged to increase the focus on applied research by more fully incorporating professionally oriented faculty into accounting education programs.

In addition to scholarly activities leading to publication, academic engagement activities in the accounting program also include editorships with academic journals, serving on editorial boards for academic journals and publications, presentation of unpublished papers at academic conferences and workshops, serving as reviewers or discussants of papers presented by others at academic conferences and workshops, and chairing or serving on committees of academic research organizations (AACSB, 2016a, 35). Academic engagement activities must be substantive in amount and sustained at levels that help the faculty member remain current and relevant in the field.

\subsection{Professional Engagement and Interaction Activities}

With the new 2013 business standards, it is suggested that business school faculty members should engage with business and management practitioners to remain current and relevant in the classroom (AACSB, 2016b, 39). Furthermore, the curricula should be designed to involve students in professional settings where they are able to connect such experiences to what is discussed in the classroom (AACSB, 2016b, 37). Faculty professional engagement activities are practice-oriented development activities that support the integration of business and management practice into the curricula (AACSB, 2016b, 39). 
According to the 2013 standards, professional engagement activities for accounting faculty include

(AACSB, 2016a, 42):

- Consulting activities

- Internships in professional practice

- Presentation of continuing professional education seminars and workshops

- Work in professional practice

- Participation in professional associations

- Practice-oriented intellectual contributions

- Service on boards of directors of professional associations or business organizations

- Participation in continuing professional education seminars and workshops

- Participation in professional events that focus on the accounting professional practice

- Participation in events that place faculty in contact with organizational leaders in accounting or management

Professional engagement activities must be substantive in that they must be meaningful and should provide for interactions with professionals for a period of time. A one-time encounter or a one-day experience with an accounting firm or accounting professional would not be considered substantive. Such an encounter may be classified as professional interaction but not as professional engagement.

Some professional engagement activities are faculty-centered activities while others are student-centered activities. For example, consulting activities, faculty internships and work in professional practice develop the faculty member directly and benefit the student through a better-prepared faculty member in the classroom. Faculty members are usually paid for these types of activities. On the other hand, participation by faculty members in professional events that focus on accounting practice or that place faculty in contact with organizational leaders on a regular basis are often student-centered activities. These activities are usually part of the strategic plan of the accounting unit and are typically classified as faculty service. According to AACSB standards, to the extent that these activities are ongoing throughout the school year and take place year after year, if they contribute to the currency and relevance of the faculty member they should be counted as professional engagement.

The standards indicate that for SA and PA faculty "there must be ongoing, sustained and substantive academic and/or professional engagement activities supporting that status" (AACSB, 2013b, 41). This statement in the standards suggests that professional engagement is not specifically required for SA 
faculty. It is up to the unit to designate whether SA faculty are required to engage with the accounting profession. PA and SP faculty may be expected to be involved in both academic and professional engagement activities. IP faculty would be expected to be involved in professional engagement activities but not academic engagement activities. If the accounting unit has 90 percent or more of SA faculty, and no staff persons to assist with arranging faculty interaction activities, the unit may need SA faculty to be involved in them. Otherwise, leadership for all such activity in the unit will be left up to the program head.

Professional interaction is defined in the accounting standards in a manner similar to that for professional engagement except that interaction is not required to be substantive or sustained. Any purposeful encounter with professionals of fifty minutes or more that contributes to the faculty member's currency and relevance in the classroom may be classified as professional interaction activities. These activities support the faculty member's currency and relevance in that they help keep the faculty member up to date concerning the knowledge and skills students need to become successful accounting professionals. Some accounting units require all accounting faculty to participate in professional events sponsored by the department or student clubs that provide opportunities for professional interaction. ${ }^{4}$

\subsection{Traditional Student/Faculty Professional Interaction Activities}

Accounting program faculty members have traditionally been required to interact with accounting professional practice for the benefit of accounting students' professional development, even before such programs were considered for AACSB accreditation. For smaller programs, this interaction is usually through professional events that focus on accounting practice. Accounting accreditation standards have supported this accounting program culture by requiring all accounting faculty to be engaged in professional interaction activities. This long-standing requirement for professional interaction is part of the AACSB's definition of high quality accounting programs. Similarly, AACSB standards have always

\footnotetext{
${ }^{4}$ Interviews were conducted via telephone with three of the 12 administrators of accounting programs classified as smaller programs with the doctorate. The 2016-2017 Hasselback directory was used for contact information.
} 
required accredited accounting programs to have some faculty on board that have professional certifications (e.g., CPA or CMA certifications ${ }^{5}$ ) and relevant work experience in accounting or business.

This tradition of faculty professional interaction is reflected in research. Bitter (2014) found that most of the 96 administrators of accredited accounting programs that responded in his study of accounting accreditation benefits did not perceive accounting accreditation to have had much impact on faculty interactions with professionals or relevant work experience. He surmised that probably due to the "professional orientation of accounting education" faculty at many institutions were already interacting with accounting practitioners and obtaining practical experience prior to these activities becoming part of AACSB standards (Bitter, 2014, 94).

Beta Alpha Psi (BAP), the honors' fraternity for financial information professionals, provides an example of a student and faculty professional interaction activity that exists in even the smallest accredited accounting programs. A BAP chapter exists only on campuses with AACSB accounting accreditation. The BAP national organization requires chapters to bring six accounting or business professionals to campus during the school year to interact with students and faculty. This is to meet the minimum chapter requirements. Chapters are incentivized by the national BAP organization to achieve more than the minimum level of interaction activity. In smaller or even in non-accredited accounting programs, there is usually an accounting club run by students, with an accounting faculty member as advisor, which is connected with a national organization with some minimum standards for student interaction. Gaharan et al (2007) conducted a survey on the benefits and challenges of accounting accreditation. Of 168 administrators of accounting program accredited as of July 2003, they received 68 responses. Of those, 62 (91\%) had a BAP student group and $35(51 \%)$ had an accounting club (21).

\footnotetext{
${ }^{5}$ These certifications are obtained by successfully completing requisite examinations offered in all U.S. states. The Uniform Certified Public Accountant Examination is required for the CPA certificate. The Certified Management Accountant Examination is required for the CMA certificate.
} 
Research shows accounting faculty perceive that some very time-consuming professional engagement and interaction activities are often not sufficiently rewarded. The Volunteer Income Tax Assistance (VITA) program is one such traditional program that has been offered in high quality accounting programs for a long time. VITA is a service learning program where students prepare tax returns for low income individuals in the community free of charge. The program is usually conducted under the supervision of an accounting faculty member and is supported by the Internal Revenue Service (IRS) office in the area. All participants must undergo training and pass an examination administered by the IRS. Accounting faculty members are required to engage with IRS personnel and other community leaders in carrying out this very beneficial experiential learning program.

Blanthorne et al (2016) analyzed active VITA programs by surveying all accounting programs listed in the Hasselback Accounting Directory. They received 311 responses out of 895 programs contacted. They found that AACSB accredited accounting programs were more likely to have VITA programs than nonaccredited accounting programs (62). And of 52 programs that had been discontinued, the reasons cited for discontinuance included excessive faculty time commitment and lack of reward for faculty effort (62).

Other traditional events or activities that foster student and faculty professional engagement and interaction in accounting programs include:

- Meet the Firms - This program is a professional event that focuses on accounting practice. It is held early in the fall semester each school year at many schools. Some schools may hold this event every semester. In this program, regional and national accounting firms and some major corporations are invited to campus to present to students and faculty about the accounting work environment and job and internship opportunities in the profession. ${ }^{6}$ This program is usually sponsored by the accounting club or Beta Alpha Psi and supported financially by the participating firms and corporations. At many institutions, accounting faculty are required to participate in this event.

- Visit the Firms - This is another program that focuses on accounting practice. Some programs arrange field trips for students to visit with local accounting firms and other companies and corporation in the regional area. An accounting faculty member usually accompanies students on the field trips and participates in the events.

\footnotetext{
${ }^{6}$ For a discussion of the Meet the Firms program being used to help recruit good students into the accounting major at Appalachian State University, see Kaenzig and Keller, 2011.
} 
- Summer Program for High School Students - Some small accounting programs offer a week-long residential program during the summer for high school students to encourage them to major in accounting. Company representatives participate directly in implementation of programs such as this one. Accounting faculty engage with professionals to arrange their participation in the program. This program focuses on accounting education and accounting student development.

- Fund-Raising for Student Activities - Funding for student interaction events and activities such as those listed above usually come from companies and firms that hire students from the accounting programs. In smaller programs, accounting faculty or the program head must engage with institutions in the process of developing funding proposals to obtain and maintain financial and other support for student professional events. Raising funds for faculty/student professional interaction activities places accounting faculty in sustained contact with organizational leaders in accounting year after year.

Smaller accounting programs that offer the doctoral degree continue to produce basic research as well as offer various interaction activities for the benefit of faculty and bachelors/masters students.

Administrators of such programs are those that view both teaching and research as the program mission (Gaharan et al, 2007). Many of these activities are unique to the accounting program and help it stand out as a "professional" program in the business school. Some programs that have sufficient resources use staff persons to work with professional accounting firms and corporations to organize and assist with the professional, student-centered activities. However, smaller programs or programs with resource challenges may not have staff available and will need to use faculty to develop and carry out these activities.

Of the three functions that faculty perform, research, teaching and service, faculty work on such studentcentered activities are usually classified as service. However, developing and maintaining these activities may indeed contribute to a faculty member's currency and relevance in the classroom, in which case, they should be classified as professional engagement or interaction. Just as research activities are classified as academic engagement, teaching and service activities may involve professional engagement and/or interaction if they contribute to a faculty member's currency and relevance. For example, having professionals speak in the classroom is an example of a teaching activity that provides professional interaction for the faculty member. Service activities may also contribute to a faculty member's currency and relevance in the classroom and should be counted as professional engagement or interaction as appropriate. Classifying these ongoing activities as professional engagement could help encourage SA 
faculty to participate in them. Otherwise, the smaller doctoral granting units with less than 10 faculty members may need faculty in other categories, such as professionally oriented faculty, to carry out these ongoing, student-focused professional engagement and interaction activities.

\subsection{Research Questions and Methodology}

\subsection{Research Questions}

In his survey of accredited accounting program administrators, Bitter (2014) found that administrators of smaller accounting programs felt more strongly than administrators of larger programs that accounting accreditation has had a positive impact on the quality of the program. This paper focuses on the need of smaller accredited accounting programs for guidance concerning effective faculty deployment to accomplish its broad mission of both high impact research and high quality professional engagement and interaction activities in accordance with AACSB standards. Administrators of smaller programs in public institutions or other programs that have resource challenges would benefit from such recommendations.

The purpose of this research is to investigate deployment practices with respect to research oriented and professionally oriented faculty in smaller and larger AACSB accredited accounting programs in public and private universities in the U.S. The research questions are:

A. Research plays an important role in the business school in fostering innovation and helping faculty maintain currency and relevance in the classroom. For accredited accounting programs, professional engagement and interaction activities are also important for both faculty and students. What mix of research oriented faculty and professional oriented faculty is used by accredited accounting programs to accomplish its unique mission of high impact scholarship and high quality professional interactions? How does the mix used by larger units differ from that used by smaller units?

B. Accounting program units that offer the doctoral degree must have a focus on both high quality basic scholarship and high-quality interactions with accounting practice. Units that do not offer the doctoral degree must also focus on research but not necessarily on basic research. Applied research is usually the focus of such programs. Applied research is by its very nature related to accounting practice so non-doctoral programs should have less resource challenges in meeting goals. How does the mix of faculty used by accredited accounting programs that offer the doctoral degree differ from that used by programs that do not offer the doctoral degree? 
C. Private institutions are expected to have less resource issues (and possibly more resources) than public institutions since they are less dependent on the state government for support. How does the mix of faculty used by public institutions differ from that used by private institutions?

\subsection{Methodology}

Based on AACSB standards, the accounting department may employ two types of faculty: participating and supporting. Participating faculty members are actively engaged in all of the activities of the school or accounting unit. Such activities include teaching as well as advising students, producing impactful research, and providing service to the university and the accounting profession. Participating faculty members usually are employed full-time. Supporting faculty members usually do not participate in the activities of the academic unit beyond teaching. These are usually part-time faculty members. The accounting department must deploy participating faculty in sufficient numbers to perform curriculum development, delivery and assessment, impactful intellectual contributions and professional engagement and interaction activities (AACSB, 2016a, 23). At least 75 percent of the curriculum must be delivered by participating faculty. Accredited business schools and accounting programs report the number of participating and supporting faculty members to the AACSB each year by completing the Accounting Programs Questionnaire (APQ), classifying them as SA, PA, SP, IP or OT (Other). Completion of the APQ is required of all accredited accounting programs.

To answer the research questions, responses to the APQ for 2015-16 were examined. On the APQ, program administrators provide the total number of participating and supporting faculty as well as the number of faculty in each category. The variables used in the study were computed by converting participating faculty in each category to a percentage of the total number of participating faculty for the unit. Participating faculty were considered to be full-time, while supporting faculty were considered to be part-time. This study focuses on participating faculty. 
The variables used are as follows:

\section{APQ Item}

Total number who are qualified as scholarly academic

Total number who are qualified as practice academic

Total number who are qualified as scholarly practitioner

Total number who are qualified as instructional practitioner

Total number who are not qualified

Total number with professional certification

Total number with recent relevant practical experience

\section{Variable Name}

$\%$ SA

$\% \mathrm{PA}$

$\%$ SP

$\%$ IP

$\%$ OT

$\%$ PROF CERT

$\%$ REL EXP

A total of 186 institutions had accounting accreditation as of November 2016. Of that number, 166 accounting programs (89\%) completed the APQ for 2015-2016. Since 2015-2016 was the first year the new faculty categories were in use, some programs had not yet defined the categories. A total of 21 institutions were removed from the study for this reason. An additional six accounting programs were removed from the study because they were foreign institutions located outside the U.S. The remaining 139 accounting programs were used in the study. Interviews were conducted with three of the program administrators of smaller programs (i.e., programs with 16 or fewer faculty members) that offer the accounting doctoral degree.

\subsection{Results and Discussion of Findings}

\subsection{Descriptive Analysis}

Table 1 provides means and medians for the sample of 139 accredited accounting programs for the number of participating faculty members and the number of supporting faculty members. The number of participating (full-time) faculty members ranged from 5 to 52 for the programs in the study with an average of 17.4 faculty members per program. Supporting (part-time) faculty ranged from zero to 35 with an average of 5.2 supporting faculty members per program. Several programs did not have any supporting faculty members.

For purposes of analysis, the sample was divided into three comparable groups: doctoral and non-doctoral programs, smaller and larger programs, and public and private institutions. The median number of participating faculty was 16 . Therefore, programs with 16 or fewer participating faculty were labeled as 
Table 1

Participating and Supporting Faculty, AACSB Accredited Accounting Programs, 2015-2016

\begin{tabular}{|c|c|c|c|c|}
\hline Attribute & Description & Mean & Median & $\begin{array}{c}\text { T-Statistic } \\
\text { (mean) }\end{array}$ \\
\hline \multirow{8}{*}{$\begin{array}{l}\text { Number of participating faculty } \\
\text { members }\end{array}$} & Range: $5-52$ & & & \\
\hline & Total sample $(\mathrm{n}=139)$ & 17.4 & 16 & \\
\hline & With doctoral program $(n=47)$ & 22.7 & 20 & \\
\hline & Without doctoral program $(n=92)$ & 14.8 & 13 & $4.68 * * *$ \\
\hline & Larger programs $(n=64)$ & 24.8 & 21 & \\
\hline & Smaller programs $(n=75)$ & 11.2 & 11 & $12.29 * * *$ \\
\hline & Public institutions $(\mathrm{n}=115)$ & 17.6 & 16 & \\
\hline & Private institutions $(\mathrm{n}=24)$ & 16.7 & 14.5 & .49 \\
\hline \multirow{8}{*}{$\begin{array}{l}\text { Number of supporting faculty } \\
\text { members }\end{array}$} & Range: $0-35$ & & & \\
\hline & Total sample & 5.2 & 4.0 & \\
\hline & With doctoral program & 6.4 & 5.5 & \\
\hline & Without doctoral program & 4.6 & 4.0 & $1.84 *$ \\
\hline & Larger programs & 6.9 & 7.0 & \\
\hline & Smaller programs & 3.8 & 3.0 & $3.91 * * *$ \\
\hline & Public institutions & 4.9 & 4.0 & \\
\hline & Private institutions & 6.5 & 7.0 & $-1.85^{*}$ \\
\hline
\end{tabular}

\footnotetext{
* Significant at the .10 level

** Significant at the .05 level

$* * *$ Significant at the .01 level
}

smaller while those with 17 or more participating faculty were labelled as larger. Of the 139 programs studied, there were 64 labelled as larger programs and 75 labelled as smaller programs. There were 47 programs that offer the doctoral degree, 81 that offer the masters' degree and 11 that offer only the bachelors' degree. For this study, the 11 bachelors' programs were included with the 81 masters' programs to make up the non-doctoral program group of 92 programs. Of the total 139 programs, 115 were in public institutions.

Programs with the doctorate have a significantly higher number of full time participating faculty members (22.7) compared to the programs without the doctorate (14.8). This difference was significant at the .05 level. Programs that offer the doctorate also appear to have more part-time (supporting) faculty members (6.4) compared to the non-doctoral programs (4.6). This different was significant at the .10 level. Based on the size of the faculty body, the units that offer the doctorate degree appear to be larger than the units that do not offer the doctorate degree. Only 12 of the programs that offer the doctorate were labelled as smaller programs with 16 or fewer faculty members. 
As expected, the larger programs have significantly more faculty on average (24.8) than smaller programs (11.2) based on separation at the median. The larger programs have an average of 6.9 part-time faculty members compared to 3.8 part-time members for the smaller programs. This difference was significant at the .01 level.

Programs in public institutions did not differ significantly from programs in private institutions on the number of full time participating faculty. However, programs in public institutions did show fewer part time supporting faculty members than programs in private institutions. This is consistent with the view that programs in private institutions have fewer resource challenges.

Faculty deployment for the entire sample is depicted in Table 2.

\begin{tabular}{lc} 
Table 2 \\
Faculty Deployment in Accounting \\
Accredited Programs, 2015-2016 \\
\hline \multicolumn{2}{c}{} \\
\hline & $\begin{array}{c}\text { Entire } \\
\text { Sample }\end{array}$ \\
\hline Number of programs & 139 \\
$\%$ SA & 68.7 \\
$\%$ PA & 6.1 \\
$\%$ SP & 2.9 \\
\% IP & 20.8 \\
\%OT & 1.6 \\
\% PROF CERT & 64.6 \\
\% REL EXP & 40.9 \\
\hline
\end{tabular}

The programs in the sample invested an average of 68.7 percent of faculty resources in the SA category, the research faculty of the unit. The standards require at least 40 percent in this category, but encourage doctoral granting units to have more than 40 percent. Investment in the two new categories, PA and SP, were small at 6.1 and 2.9 percent, respectively. This was expected as 2015-16 was the first year these new categories were used. At least 60 percent is required for the SA, PA and SP categories combined. The programs in the study more than meet this standard.

The programs invested an average of 20.8 percent of faculty resources in the IP category where most of the professional activities of the unit occur. Up to 40 percent is allowed in this category. Faculty classified 
in the two new categories, PA and SP, may be expected work on both research and professional engagement and interaction activities. Amounts invested in these categories are expected to increase in future years.

AACSB accounting standards require accredited units to have some faculty on board with professional accounting credentials, qualifications, certifications and professional experience if the mission of the program is to prepare students to attain these credentials and certifications (AACSB, 2016a, 31). For the programs in the study, 64.6 percent of participating faculty members has some type of professional certification and 40.9 percent have recent relevant experience.

\subsection{Faculty Deployment, Doctoral versus Non-Doctoral Units}

The percentage of total participating faculty deployed by accredited accounting programs in each of the faculty categories for the 139 programs in the sample are shown in Table 3 for doctoral and non-doctoral programs. There were 47 programs in the sample that offer the doctoral degree and 92 programs that do not. The percentage of participating faculty deployed in the scholarly academic (SA) category did not differ significantly between doctoral and non-doctoral units. Both program levels deploy approximately 69 percent of total participating faculty to academic engagement activities. The standards require at least 40 percent in this category but encourage doctoral granting units to more than meet this standard. At least 60 percent is required for the SA, PA and SP categories combined. All three of these faculty groups are likely to be involved in research activities, especially in the smaller accounting programs. When the three categories are added for the programs in the sample, programs with the doctoral degree have 77.9 percent and programs without the doctoral degree have 77.5 percent of participating faculty resources invested in these three categories, still not much of a difference between the groups, but well in excess of the 60 percent requirement.

Also, both groups of units, doctoral and non-doctoral, deploy approximately the same percentage of participating faculty to the IP category, approximately 21 percent. The average amount deployed to the 
Table 3

Faculty Deployment in Accounting Accredited Programs, Doctoral Programs versus Non-Doctoral Programs, 2015-2016

\begin{tabular}{lccc}
\hline & $\begin{array}{c}\text { Programs with } \\
\text { Doctoral Degree }\end{array}$ & $\begin{array}{c}\text { Programs without } \\
\text { Doctoral Degree }\end{array}$ & t-statistic \\
\hline No. of programs & 47 & 92 & \\
\% SA & 68.6 & 68.7 & -.05 \\
\%PA & 7.5 & 5.4 & 1.53 \\
\%SP & 1.8 & 3.4 & $-1.96^{* *}$ \\
\%IP & 20.5 & 20.9 & -.20 \\
\%OT & 1.6 & 1.6 & \\
\% PROF CERT & 54.0 & 70.1 & $-3.35^{* * *}$ \\
\% REL EXP & 37.8 & 42.5 & .84 \\
\hline *- Significant at the .10 level & & \\
**- Significant at the .05 level & & \\
$* * *$ - Significant at the .01 level & &
\end{tabular}

SA and IP categories for doctoral and non-doctoral accredited accounting programs is the same as the average amount deployed to these categories for the total sample of 139 programs (see Table 2).

Accounting programs with the doctorate have fewer faculty members with professional certification (54\%) compared to non-doctoral programs $(70.1 \%)$. This difference is significant at the .01 level. This result is consistent with the goals of the programs. Doctoral programs focus more on academic research than on professional practice and interaction. Programs with the doctorate also showed fewer faculty members having recent relevant experience although the difference from non-doctoral programs was not significant. It is worthwhile to note, however, that both groups of programs have a good number of faculty members with recent experience, an average of 38-43 percent. This is in line with the total sample which showed 40 percent of faculty having recent experience (Table 2). Faculty with recent experience usually represent professionally oriented faculty (e.g., currently for formerly practicing CPAs or lawyers) that work full or part-time for the accounting program. Having a high number of practicing professionals on the faculty should help programs carry out PEI activities.

\subsection{Faculty Deployment, Smaller versus Larger Units, Doctoral and Non-Doctoral}

Deployment statistics for the sample when separated into smaller and larger programs are shown in Table 4. The smaller accounting units deploy approximately the same percentage of faculty toward the SA category as the larger programs, 69.5 versus 67.7 percent. The difference was not significant. The smaller 
Table 4

Faculty Deployment in Accredited Accounting Programs, Smaller Versus Larger

Programs, 2015-2016

\begin{tabular}{lccc} 
& Smaller Programs & Larger Programs & t-statistic \\
\hline No. of programs & 75 & 64 & \\
\% SA & 69.5 & 67.7 & .91 \\
\%PA & 5.5 & 6.8 & -1.02 \\
\%SP & 2.5 & 3.3 & -.77 \\
\% IP & 20.6 & 21.0 & -.19 \\
\%OT & 1.9 & 1.3 & \\
\% PROF CERT & 69.0 & 59.6 & $2.08 * *$ \\
\% REL EXP & 42.9 & 38.7 & .82 \\
\hline *Significant at the .10 level & & \\
** Significant at the .05 level & & \\
*** Significant at the .01 level & & &
\end{tabular}

accounting units deploy approximately the same percentage of faculty toward the IP category as the larger programs as well, 20.6 versus 21 percent. Again, the difference was not significant.

Smaller programs do show more professionally certified faculty than the larger programs, 69 percent versus 59.6 percent. This difference is significant at the .05 level. This is probably because most of the doctoral programs are in the larger program group and doctoral programs focus more on research than on practice. Smaller programs also show more faculty members having practical experience than the larger programs but the difference is not significant.

When we look at the size of programs that offer the doctoral degree (Table 5), we find that the smaller programs that offer the doctorate deploy almost 74 percent of the participating faculty resources to the SA category compared to 67 percent for the larger such programs (t-tests were not computed for this section of the table due to the small sample size for the smaller programs). It makes sense that smaller programs would devote as much of its faculty resources to research as possible, especially doctoral programs that focus on basic research. Such units seek to have a good quantity of high quality research to meet accreditation standards for $\mathrm{PhD}$ programs. A few of the units in this group of smaller programs with the doctorate devote as much as 89 percent of its faculty resources to the SA category.

On the other hand, for programs without the doctoral degree, both smaller and larger institutions devote the same amount of faculty resources to the SA category (about 69 percent). These institutions probably 
Table 5

Faculty Deployment in Accounting Accredited Programs, Doctoral Versus Non-Doctoral, Smaller Versus Larger Programs, 2015-2016

\begin{tabular}{|c|c|c|c|c|c|c|}
\hline & \multicolumn{3}{|c|}{$\begin{array}{c}\text { Programs with Doctoral } \\
\text { Degree }\end{array}$} & \multicolumn{3}{|c|}{$\begin{array}{l}\text { Programs without } \\
\text { Doctoral Degree }\end{array}$} \\
\hline & $\mathrm{S}$ & $\mathrm{L}$ & t-stat & $\mathrm{S}$ & $\mathrm{L}$ & t-stat \\
\hline No. of programs & 12 & 35 & $\mathrm{n} / \mathrm{a}$ & 63 & 29 & \\
\hline$\%$ SA & 73.7 & 66.8 & $\mathrm{n} / \mathrm{a}$ & 68.7 & 68.7 & .03 \\
\hline$\% \mathrm{PA}$ & 6.8 & 7.7 & $\mathrm{n} / \mathrm{a}$ & 5.2 & 5.8 & -.16 \\
\hline$\% \mathrm{SP}$ & .8 & 2.2 & $\mathrm{n} / \mathrm{a}$ & 2.9 & 4.5 & -1.56 \\
\hline$\% \mathrm{IP}$ & 16.7 & 21.8 & $\mathrm{n} / \mathrm{a}$ & 21.3 & 19.9 & .60 \\
\hline$\% \mathrm{OT}$ & 2.1 & 1.4 & $\mathrm{n} / \mathrm{a}$ & 1.8 & 1.1 & \\
\hline$\%$ PROF CERT & 57.7 & 52.7 & $\mathrm{n} / \mathrm{a}$ & 71.1 & 67.8 & .50 \\
\hline$\%$ REL EXP & 36.0 & 38.4 & $\mathrm{n} / \mathrm{a}$ & 44.2 & 39.0 & .80 \\
\hline
\end{tabular}

focus mostly on applied and pedagogical research as opposed to basic research required of doctoral programs.

When the SA, PA and SP categories are combined as required by the standards, we see that the smaller programs with the doctorate more than meet the 60 percent threshold. These programs have approximately 81.3 percent of participating faculty resources invested in the three categories that produce research. This compares to 76.7 percent for the larger programs with the doctorate.

The smaller accounting units with doctoral programs invest less of its faculty resources $(16.7 \%)$ in the IP category compared to the larger such units $(21.8 \%)$. The standards allow up to 40 percent in the IP category although doctorate granting programs are encouraged to have less than 40 percent in this category. Some $50 \%$ of the units in the smaller doctoral group $(n=12)$ invested less than $20 \%$ of its participating faculty in the IP category. For institutions with 10 or fewer faculty members, this means one or less faculty member may be available for PEI activities. For non-doctoral units, smaller and larger programs invest a similar amount in the IP category, 21.3 percent versus 19.9 percent, respectively. The difference was not significant.

Both smaller and larger units have a high percentage of faculty holding professional certifications in both groups, doctoral and non-doctoral. However, the non-doctoral units do have a higher percentage of 
faculty members with professional certification than the doctoral units. Also, for both smaller and larger programs, the percentage with recent relevant experience is lower for doctoral units than for the nondoctoral units. Again, this result was expected since doctoral programs focus more on basic research. It is not necessary for such programs to have a large number of faculty members with professional experience. On the other hand, the masters and baccalaureate programs are expected to have a high percentage of faculty members that may be CPAs or are currently practicing. Such faculty can help programs carry out high quality PEI activities for students and faculty including research related to practice. As expected, these programs do show higher amounts of faculty with experience than the doctoral programs.

Overall, the smaller programs in the study tend to have a higher percentage of faculty members with professional certification and relevant experience than the larger programs. This is shown in Tables 4 and 5. However, due to the focus on research, a few of the smaller units with the doctoral program have zero or very few faculty with relevant practical experience. Table 5 shows that the smaller programs with the doctorate have fewer faculty members with experience (36\%) than the larger such programs (38\%), just the opposite of what was expected.

\subsection{Deployment of Faculty, Public versus Private Institutions}

The percentage of total participating faculty in each of the faculty categories are shown in Table 6 by type of institution, i.e., public versus private. It was expected that private institutions will have fewer challenges related to faculty resources than public institutions. Based on the data, accredited accounting programs in public and private institutions invest about the same amount in the SA category, about 69 percent. The investment in the IP category is also similar for programs in public and private institutions at 20-21 percent. Due to the small sample size for private institutions, t-tests were not conducted for Table 6.

\subsection{Discussion of findings}

The most significant finding of this research is that, on average, AACSB-accredited accounting programs deploy 67-70 percent of participating faculty resources toward the SA category in support of research 
Table 6

Faculty Deployment in Accredited Accounting Programs, Public Versus Private Institutions, 2015-2016

\begin{tabular}{lcc}
\hline & $\begin{array}{c}\text { Public } \\
\text { Institutions }\end{array}$ & $\begin{array}{c}\text { Private } \\
\text { Institutions }\end{array}$ \\
\hline No. of programs & 115 & 24 \\
\% SA & 68.7 & 68.5 \\
\% $P A$ & 6.0 & 6.4 \\
\%SP & 2.8 & 3.1 \\
\%IP & 20.9 & 20.2 \\
\%OT & 1.6 & 1.8 \\
\% PROF CERT & 63.9 & 68.2 \\
\% REL EXP & 39.6 & 47.2 \\
\hline
\end{tabular}

oriented faculty and approximately 21 percent toward the IP category in support of professional oriented faculty. This was found to be true for the total sample as well as for small and large institutions, doctoral and non-doctoral programs, and public and private institutions. However, when doctoral programs were separated into larger and smaller groups, it was found that smaller units with the doctoral program invest up to 74 percent of faculty resources in research oriented faculty while the larger doctoral units invest only about 67 percent in research oriented faculty. Similarly, smaller units with the doctoral program invest only 17 percent in the IP category compared to 22 percent for the larger such units. The nondoctoral units, both smaller and larger, invest approximately 69 percent in the SA category and 20-21 percent in the IP category.

To ensure that this result was not just a one-year phenomenon, the APQ was examined for 2010-2011, five years prior to 2015-2016 school year, to determine deployment practices for AQ and PQ at that time. Table 7 is a summary of that result. The sample for 2010-2011 consisted of 123 accredited accounting programs that completed both the 2010-2011 and the 2015-2016 questionnaire. Table 7 shows that the programs invested approximately 72 percent in the AQ category and 24 percent in the PQ category in 2010-2011. When the sample was separated into the various groups used in the study, the investment in the categories for the groups were very similar to that of the total sample ranging from 71-77 percent in AQ and 20-25 percent in PQ. The variation for the smaller doctoral units existed in 2010-2011 the same as it did for 2015-2016. These smaller doctoral programs invested more in the AQ category (77\%) and 
Table 7

Faculty Deployment ibn Accounting Accredited Programs, Public Versus Private Institutions, 2010-2011

\begin{tabular}{lccccccccccc}
\hline & Large & Small & PhD & $\begin{array}{c}\text { Non } \\
\text { PhD }\end{array}$ & $\begin{array}{c}\text { Large } \\
\text { PhD }\end{array}$ & $\begin{array}{c}\text { Small } \\
\text { PhD }\end{array}$ & $\begin{array}{c}\text { Large } \\
\text { Non } \\
\text { PhD }\end{array}$ & $\begin{array}{c}\text { Small } \\
\text { Non } \\
\text { PhD }\end{array}$ & Public & Private & $\begin{array}{c}\text { Total } \\
\text { Sample }\end{array}$ \\
\hline No. of programs & 60 & 63 & 44 & 79 & 33 & 11 & 25 & 54 & 100 & 23 & 123 \\
\%AQ & 71 & 73 & 73 & 72 & 71 & 77 & 73 & 71 & 72 & 74 & 72 \\
\%PQ & 25 & 23 & 23 & 24 & 24 & 20 & 24 & 25 & 24 & 23 & 24 \\
\%OT & 3 & 3 & 4 & 3 & 4 & 3 & 3 & 3 & 3 & 3 & 3 \\
\% PROF CERT & 59 & 70 & 53 & 71 & 50 & 61 & 73 & 69 & 64 & 68 & 65 \\
\% REL EXP & 40 & 45 & 34 & 49 & 34 & 34 & 47 & 49 & 41 & 48 & 43 \\
\hline
\end{tabular}

less in the PQ category (20\%) than the larger such programs (71 and 24 percent for AQ and PQ, respectively).

If smaller doctorate-granting units are having difficulty meeting goals related to professional engagement and interaction, this finding could explain why. Smaller units should strive to invest around 68-70 percent in SA, and at least 20-25 percent in IP, SP and PA. Based on 2015-2016 data, large and small accredited accounting programs and both doctoral and non-doctoral programs in public and private schools use this approximate mix of research oriented and professionally oriented faculty. A similar pattern was noted in data from five years earlier (2010-2011) where programs invested around 72 percent in the AQ category and up to 24 percent in the PQ category.

Another important finding from this study is that, on average, approximately 41 percent of the full time faculty of AACSB accredited accounting programs were classified as having recent relevant experience for 2015-2016. In units with doctoral programs, 36-38 percent of the faculty members have recent experience. The non-doctoral units have a higher percentage (68-71\%) of faculty receiving experience. A similar pattern appeared in the 2010-2011 data in that 43 percent of the participating faculty members in the total sample were listed as having recent relevant experience for the school year. The non-doctoral programs showed a higher percentage of faculty with relevant experience than the doctoral programs. For 2015-2016, some of the smaller programs with the doctorate showed zero or very few faculty with relevant experience. An increase in professionally oriented faculty for these programs would likely increase this percentage. 


\subsection{Conclusions, Limitations and Additional Research}

\subsection{Conclusions and Recommendations}

AACSB accredited accounting programs that offer baccalaureate, masters and doctorate degrees in accounting have a mission that includes both high quality research and high quality interactions with the accounting profession. This paper shows that most AACSB accredited accounting programs deploy approximately 20-21 percent of participating faculty to the IP faculty category which usually involves professional engagement and interaction activities. These programs also have small amounts invested in the PA and SP categories which also contribute partially to professional activities. Research oriented faculty members, usually classified as SA, are not required by the 2013 accreditation standards to perform these activities. SA faculty may be completely devoted to research. On average, AACSB accredited accounting programs invests approximately 69 percent of faculty resources in the SA category.

AACSB standards encourage business schools to embrace impact, innovation and engagement in business and accounting education programs. High quality interactions with accounting professional practice are a hallmark of high quality accounting education programs. Furthermore, the Pathways Commission was created in response to a U.S. Treasury concern that accounting education may not be meeting the needs of U. S. auditing practice. The Commission has recommended that professionally oriented faculty be integrated more fully into accounting education. This recommendation, if implemented, is expected to help meet the needs of auditing practice as well as help accounting education deal with the shortage of terminally qualified faculty.

Administrators of smaller accounting units that may be facing difficulty accomplishing professional engagement and interaction goals and strategies should plan for investment in the faculty categories for professionally oriented faculty of at least 20 percent for IP, and up to 25 percent with the PA and SP categories included. If an increase is needed such units could focus on increasing the PA and SP categories first as these faculty are more likely to contribute to both academic and professional 
engagement activities. New faculty entering accounting academia from accounting practice, many with DBA degrees from AACSB accredited institutions, should be considered for some of these positions. This recommendation supports the Pathways Commission recommendation that accounting programs should more fully integrate professionally oriented faculty into accounting education programs.

AACSB accounting accredited programs showed a high percentage of faculty having relevant experience during the school year, approximately 41 percent for the entire sample. Programs with the doctoral degree show approximately 38 percent of faculty members having relevant experience. However, some of the smaller programs with the doctoral degree show zero or very few faculty with relevant experience. Administrators of programs experiencing difficulty with professional engagement goals may consider increasing the number of participating faculty with recent relevant experience. Such faculty, usually classified as PA, SP or IP faculty, are more likely to be involved in accounting or law practice and could bring practical experience to the accounting program on an ongoing basis. These faculty have much to contribute toward implementing high quality professional engagement and interaction activities.

University administrators should be cognizant of the need of the accounting program and other business fields for professional engagement and interaction activities for the benefit of students and faculty development, and for meeting accreditation standards. If the unit has staff persons on board to help organize and arrange such activities, this may not be an issue for the unit. However, if resources are scarce and staff persons are not available to assist with these engagement activities, professionally oriented faculty will be needed. Some colleges and universities may require all faculty to be tenure track, a policy that may not easily accommodate professionally oriented faculty. Some accommodation for clinical faculty, or a professor of practice category, may need to be considered by university administration to allow sufficient faculty slots for accounting professionals to serve in the accounting program. For example, an accounting program with 10 full-time faculty slots should have at least two slots $(20 \%)$ available to professionally oriented faculty in the PA, SP or IP categories. This would allow sufficient faculty for small programs to cover traditional professional activities including the VITA 
program and faculty advisorships for two student clubs, BAP and the accounting club. The student clubs help the unit sponsor professional events that impact both students and faculty. Faculty qualified at the PA level could be tenure track. In the interest of continuous improvement, smaller units that currently have 10 or fewer faculty with less than 20 percent professionally oriented faculty should look to obtain one or two additional faculty slots rather than decreasing the slots devoted to research.

Deans and accounting program administrators should look for ways to reward participating non-tenure track accounting faculty for academic and student-centered professional engagement activities. This would allow faculty who manage the VITA program, for instance, or who help students bring accounting professionals to campus each school year to meet BAP requirements, to use these activities to maintain qualification. Indeed, these activities may be substantive and sustained to the extent that programs are required to cultivate long-term relationships in the accounting professional community to meet BAP and other student club requirements.

\subsection{Limitations and Additional Research}

One limitation of this research is that it examines only one year of data in seeking to define a trend in faculty deployment for accredited accounting programs. This limitation is caused by the fact that the new faculty categories began in the new 2013 AACSB standards and were not put into operation until the 2015-2016 school year. However, accounting units are not expected to be able to make extreme changes in faculty mix over the short term. Data from five years earlier (2010-2011) shows that programs held an investment in academically qualified faculty versus professionally qualified faculty $(A Q / P Q)$ in a manner similar to that held for the SA/IP categories in 2015-2016. As noted, the SA/IP categories in the 2013 standards replaced the AQ/PQ categories in the 2003 standards.

Another limitation of this research is that the sample sizes were small when the sample was divided into certain groups, especially the smaller doctoral program group. This research is directed toward that group. Small sample sizes are not appropriate for conducting statistical t-tests of mean differences. However, the 
focus of this research is more related to similarities in the data than differences since its purpose is to document a trend in faculty deployment practices. T-tests were not computed when the sample sizes were considered too small.

Additional research is needed to consider future years of data submitted to the AACSB's APQ database to see if the use of professionally oriented faculty in the accounting unit increases in the future as recommended by the Pathways Commission. The new faculty categories of PA and SP are designed to give programs more opportunities and flexibility to use professional faculty. It is expected that the use of these categories of faculty will increase over time.

Other research should also look at the business school data submitted to the AACSB each year to determine the extent to which areas of the business school other than accounting are utilizing professionally oriented faculty as recommended by the 2013 AACSB standards.

The perceived disconnect between accounting research and accounting and auditing practice (Behn et al, 597, Pathways Commission, 2012) also warrants further investigation. 


\section{References}

Association to Advance Collegiate Schools of Business (AACSB) (2016a). Eligibility procedures and accreditation standards for accounting accreditation.

AACSB (2016b). Eligibility procedures and accreditation standards for business accreditation.

Behn, B. K., Ezzell, W. F., Murphy, L. A., Rayburn, J. D., Stith, M. T. \& Strawser, J. R. (2012) The Pathways Commission on accounting higher education: charting a national strategy for the next generation of accountants. Issues in Accounting Education, 27(3), 595-600.

Bishop, C. C., Boyle, D. M., Carpenter, B. W. \& Hermanson, D. R. (2016). Transitioning into academia: a new pathway for practitioners. Journal of Accountancy, March, 48-53.

Bishop, C. C., Boyle, D. M., Clune, R. \& Hermanson, D. R. (2012). A different model for doctoral education in accounting and auditing: Student and faculty reflections. Current Issues in Auditing, 6(1), A1-A16.

Bitter, M. E. (2014). The benefits of AACSB accounting accreditation: Perceptions of administrators of accounting accredited programs. Academy of Educational Leadership Journal, (18) 1, 85-103.

Blanthorne, C. \& Westin, S. (2016). VITA: A comprehensive review of the literature and an analysis of the program in accounting education in the U.S. Issues in Accounting Education, 31(1), 51-69.

Boyle, D. M., Carpenter, B. W. \& Hermanson, D. R. (2015a). The accounting faculty shortage: Causes and contemporary solutions. Accounting Horizons, (29)2, 245-264.

Boyle, D. M., Carpenter, B. W., Hermanson, D. R. \& Mero, N. P. (2015b). Examining the perceptions of professionally oriented accounting faculty. Journal of Accounting Education, 33, 1-15.

Buckley, M.R., Ferris, G. R., Bernardin, H. J. \& Harvey, M. G. (1998). The disconnect between the science and practice of management. Business Horizons, March/April, 31-38.

Corcoran, C. P. (2006). AACSB accredited business programs: differences and similarities. Journal of Business \& Economic Research, August, 4(8), 41-48.

Francisco, W., Noland, T. G., \& Sinclair, D. (2008) AACSB accreditation: Symbol of excellence or march toward mediocrity? Journal of College Teaching and Learning, May, (5) 5, 25-29.

Gaharan, C., Chiasson, M. A., Foust, K. M. \& Mauldin, S. (2007). AACSB international accounting accreditation: Benefits and challenges. The Accounting Educators' Journal, (17), 13-19.

Hasselback, J., (2017). A directory of accounting faculty 2016-2017. Available online at:

www.jrhasselback.com.

Iniguez S. (2016). The next phase of business education. BizEd, September/October, 50-54.

Kaenzig, R. \& Keller, R. (2011). A comprehensive effort to recruit and retain accounting students. Journal of Accounting Education, 29, 315-323.

Kren, L., Tatum, K. W. \& Phillips, L. C. (1993). Separate accreditation of accounting programs: An empirical investigation. Issues in Accounting Education, (8)2, 260-272.

Pathways Commission. (2012). Charting a national strategy for the next generation of accountants.

Rebele, J. E. \& Kent St. Pierre, E. (2015). Stagnation in accounting education research. Journal of Accounting Education, 33, 128-137.

Schneider, G.P. \& Sheikh, A. (2012). Addressing the shortage of accounting faculty: Using non-tenuretrack positions. Academy of Educational Leadership Journal, 16(1), 1-18.

Sinning, K. E. \& Dykxhorn, H. J. (2001). Processes implemented for AACSB accounting accreditation and the degree of faculty involvement. Issues in Accounting Education, (16)2, May, 181-204.

Subhabrata, B. \& Morley, C. (2013). Professional doctorates in management: toward a practice based approach to doctoral education. Academy of Management Learning and Education, 12(2), 173-193.

Trapnell, J. E. \& Showalter, D. S. (2015). Practical balance. BizEd, September/October, 46-50.

Trapnell, J. E. \& Williams, J.R. (2012). AACSB international: An update and perspective. Issues in Accounting Education, 27(4), 1071-1076.

Yunker, J. A. (2000). Doing things the hard way-problems with mission-linked AACSB accreditation standards and suggestions for improvement. Journal of Education for Business, July/August, 346-353. 